\title{
МЕДІАЦІЯ В УКРАЇНІ: ПРОБЛЕМИ ТРАНЗИТИВНОГО ПЕРІОДУ
}

Матвєєва Л. Г., Балтаджи П. М.

Сучасне українське суспільство характеризується нестабільністю, високою соціально-економічною динамікою і невизначеним «вектором» змін, що дає змогу вважати його транзитивним. Велике значення у формуванні правової культури вирішення спорів в Україні останнім часом набуває інститут медіації. За сучасних умов українське суспільство потребує медіації майже в усіх видах правовідносин. Свідченням тому $\epsilon$ створення в Украйні низки громадських організацій, які поширюють медіацію на території України. Термін «медіація» походить від грецького medos («нейтральній, незалежний від сторони»), а також від латинських термінів mediatio («nосередництво») ma mediare («бути посередником у спорі»). Медіація сприяє прискореному розвитку інститутів громадянського суспільства, де головним суб'єктом виступає людина з усією системою її потреб, інтересів і цінностей.

Устатті розглядається питання про становлення та розвиток медіації як нового соціально-правового інституту вітчизняного права в умовах транзитивного періоду. Аналізуються проблеми та перспективи ефективного впровадження та використання інституту медіації як самостійного способу вирішення спорів в сучасній Україні та перспективи його розвитку, що загалом сприяє підвищенню рівня соціальної злагоди і взаємодії в соціумі. Акцентується на тому, що інститут медіації поряд з іншими альтернативними способами регулювання спорів $є$ ознакою розвиненого громадянського суспільства, показником високого рівня правової культури та найважливішим критерієм розвитку демократії. Звертається увага на переваги медіації для розвитку партнерських відносин та гармонізації соціальних відносин. Робиться висновок, що законодавче регулювання процедури медіації розширить альтернативні способи вирішення спорів, дасть змогу сторонам врегулювати спір у позасудовому порядку, що сприятиме вдосконаленню в Україні механізмів захисту прав людини і громадянина. Сформульовано висновок щодо перспектив інтеграції медіації у правову систему України.

Ключові слова: конфлікт, медіація, інститут медіації, інновація, альтернативне вирішення спорів, правова культура, транзитивне суспільство, громадянське суспільство.

Matvieieva L. H., Baltadzhy P. M. Mediation in Ukraine: problems of transitive period

Modern Ukrainian society is characterized by instability, high socio-economic dynamics and an uncertain "vector" of change, which makes it possible to consider it transitive. Recently, the Institute of Mediation has become increasingly important in shaping the legal culture of dispute resolution in Ukraine which is gaining in popularity. In today's context, Ukrainian society requires mediation in almost all legal relationships. This is evidenced by the creation in Ukraine of a number of NGOs that distribute mediation in Ukraine. The term "mediation" comes from the Greek medos (neutral, partyindependent), as well as from the Latin terms mediatio (mediation) and mediare (to mediate). Mediation facilitates the accelerated development of civil society institutions, where a person with the whole system of his needs, interests and values is the main subject.

The article deals with the issue of formation and development of mediation as a new social-law institute of domestic law at transitional period. The problems of effective introduction of the mediation institute in modern Ukraine and the prospects of its development are analyzed. Emphasis is made to the fact that the Mediation Institute, along with other alternative ways of dispute settlement, is a sign of a developed civil society, an indicator of a high level of legal culture and maturity of economic turnover, the most important criterion for the development of democracy. Attention is drawn to the benefits of mediation for the development of partnerships and the harmonization of social relations. The conclusion is made concerning the prospects of integration of mediation into the legal system of Ukraine.

Under the current conditions, the mechanism of introduction of the Institute of Mediation is gaining momentum. Scientists, judges, lawyers, and civil society representatives all agree that mediation is an effective alternative to litigation. The development of the pre-trial procedure in Ukraine is becoming increasingly popular and will facilitate the rapid emergence of civil society, within which citizens can truly regulate conflicts without government involvement and control.

Key words: alternative dispute resolution, civil society, conflict, innovation, institute of mediation, legal culture, mediation, transitive society.

Постановка проблеми та їі актуальність. Транзитивні зміни, що відбуваються в сучасному суспільстві, провокують кардинальні пере-

(с) Матвєєва Л. Г., Балтаджи П. М., 2020 
творення усіх суспільних інститутів. Для успіху соціальних трансформацій та завершення стану транзитивності вкрай важливою $\epsilon$ організація управління соціальними процесами. В сучасних умовах, коли в Україні триває реформування судової системи і підвищується кількість судових звернень, особливої актуальності набуває питання активного впровадження альтернативних процедур вирішення спорів. Дедалі частіше медіацію пропонують як рятувальний круг у бурхливих хвилях конфлікту. Інститут медіації, по суті, $\epsilon$ інноваційним для українського національного менталітету, а складнощі сприйняття донедавна були пов'язані з відсутністю чіткого усвідомлення переваг i, як наслідок, недовірою, як i до багатьох інновацій у суспільстві. Нині скепсис щодо відповідності медіації правовій культурі та ментальності українського суспільства змінився інтересом, який провокує широкі дискусії та активні обговорення впровадження медіації як способу вирішення конфліктів.

Аналіз останніх досліджень та публікацій. Проблеми й перспективи становлення та розвитку вітчизняного інституту медіації як альтернативного способу вирішення конфліктів $\epsilon$ актуальною темою дискусій і науково-практичних досліджень багатьох науковців, практиків, представників політикуму. Предметом виступають як загальні питання сутності медіації, так і проблеми запровадження медіації в окремих галузях права (Т. Барабаш, А. Гірник, Н. Грень, Р. Денисова, Ю. Рємєскова, Л. Романадзе, Н. Крестовська, Т. Шинкар та ін.). Роботи сучасних дослідників становлять наукове підґрунтя для подальшого дослідження інституту медіації в Україні, актуалізують проблему законодавчого врегулювання правового інституту медіації та його інтеграції в сучасну правову систему України.

Метою статті $\epsilon$ аналіз та дослідження проблематики щодо становлення та впровадження інституту медіації в умовах транзитивного розвитку українського суспільства, визначення ролі інституту медіації для вдосконалення механізмів захисту прав людини і громадянина в Україні.

Виклад основного матеріалу. Розуміння медіації як нововведення $\epsilon$ свідченням неповноти інформаційної картини в суспільній свідомості. Інститут має довгу історію в багатьох культурах i цивілізаціях. Залучення авторитетних людей до виконання ролі посередника відоме з давніх часів. У Стародавньому Китаї, Стародавній Греції, Персії, в арабських країнах існувала традиція звернення до авторитету, щоб подолати розбіж- ності, вирішити конфлікт. Світські володарі, які здійснювали правосуддя в своїх володіннях, вважали полагодження спору між своїми васалами в певних випадках більш бажаним, аніж винесення вироку [1, с. 167].

Тісний зв'язок елементів примирення та відновного правосуддя простежується і в українській правовій традиції, що знайшло відображення у практиці та нормативному забезпеченні примирення часів Київської Русі. Йшлося, як зазначає А. Гірник, про некаральні суспільні засоби впливу на правопорушника, що перепліталися з дохристиянськими звичаями, релігійними нормами та політичними практиками, які знаходили прояв у компенсації завданої правопорушником шкоди, процедурах побратимства, хресного цілування, якими завершувалося i закріплювалося укладення примирної угоди [1, с. 168].

Кодекси звичаєвого права багатьох народів Західної Європи віддзеркалювали традицію «відновлювального правосуддя», яка зберігала актуальність до середини XIX ст. Окремі регіони Західної України зберігали дію звичаєвого права в діяльності копних судів, метою яких було встановлення справедливості та примирення сторін, а отже, підтримання миру в громаді.

Медіація в іï сучасному розумінні почала розвиватися в другій половині XX ст., перш за все в країнах англо-саксонського права - США, Австралії, Великобританії. У країнах континентальної системи права - Франції, Бельгї, Німеччині, Австрії, Італії, Швейцарії, Нідерландах - про медіацію стало відомо наприкінці 80-х - початку 90-х років XX ст. Досвід сучасних країн доводить ефективність вирішення конфліктів за участю професійного посередника, а вирішення спору до суду вважається сприятливою практикою і всіляко заохочується в Японії і Китаї.

Впровадження інституту медіації в Україні змістовно пов'язує сучасний розвиток правової системи України з європейськими правовими системами, цінностями та пріоритетами розвитку сучасного цивілізованого світу. Становлення та розвиток медіації в Україні протягом останніх десятиліть дає підстави стверджувати, що такий метод вирішення спорів набув статусу соціального інституту. Мирне вирішення конфлікту - ознака української ментальності, а стан вітчизняної судової системи спонукає громадян шукати та застосовувати альтернативні процедури вирішення спорів. Крім того, йдеться про наявність стійкого соціального запиту на реформування судової гілки влади, покращення доступу до правосуддя, 
зниження рівня конфліктності у суспільстві. За таких умов інститут медіації розглядається як одне з органічних доповнень державної судової системи.

Разом із тим І. Ясиновський констатує, що в Україні впровадження медіації здійснюється надто повільними темпами, порівняно з іншими державами, а серед головних проблем впровадження медіації в України автор називає низький рівень правової культури населення, низький рівень довіри до медіативної послуги, недостатню поінформованість громадян про медіацію, її переваги як альтернативного судовому розгляду, позиції сторін, які не бажають іти на компроміс, специфіку національного правосуддя, низький рівень співпраці 3 міжнародними організаціями, відсутність належної фінансової підтримки, складність вибору медіатора як високопрофесійної особи, відсутність спеціалізованого законодавства [16, с. 261-264].

За сучасних умов багато суперечок викликає питання прийняття спеціалізованого законодавства у сфері медіації. Починаючи з 2010 р. за ініціативи фундаторів української медіації та за підтримки парламентарів у Верховній Раді України зареєстровано десять законопроєктів про медіацію. Однак через нестабільну політичну ситуацію, постійні зміни урядів і парламентські вибори закон досі не прийнято [2, с. 6]. Так, 28 лютого 2019 р. Верховна Рада України відхилила законопроєкт № 3665 «Про медіацію», який розглядався у другому читанні. Законопроєкт передбачав формування правових засад та порядку проведення медіації як позасудової процедури врегулювання конфлікту, принципи медіації, статус медіатора. Визначалося, що медіація може застосовуватися в будь-яких конфліктах, у тому числі цивільних, сімейних, трудових, господарських, адміністративних, а також у провадженні щодо кримінальних проступків, злочинів невеликої чи середньої тяжкості та в кримінальному провадженні у формі приватного обвинувачення, передбаченого ст. 477 КПК України, та справах про адміністративні правопорушення [10]. Інший законопроєкт «Про діяльність у сфері медіації» № 10425 був знятий з розгляду у зв'язку з розпуском Верховної Ради [8].

15 липня 2020 р. Верховна Рада України прийняла за основу поданий Кабінетом Міністрів України проєкт Закону України «Про медіацію» (№ 3504), який на законодавчому рівні закріплює проведення процедури медіації. Комітету Верховної Ради України з питань правової політики доручено доопрацювати зазначений законопроєкт з урахуванням зауважень і пропозицій суб'єктів права законодавчої ініціативи [9]. Таким чином, зазначається висока активність суб'єктів законодавчої ініціативи, спрямована на врегулювання в Україні медіації.

Розвиток альтернативних способів вирішення спорів передбачений Стратегією реформування судоустрою, судочинства та суміжних правових інститутів на 2015-2020 роки, затвердженою Указом Президента України від 20.05.2015 р. № 276. Водночас ані в українського законодавця, ані у суспільства немає розуміння ефективного механізму інкорпорації альтернативних способів вирішення спорів у правову систему держави [13].

Україна знаходиться в ситуації, коли практика використання процедури медіації йде попереду правового регулювання. Попри відсутність спеціального законодавства, медіація презентується як найпростіша, найпоширеніша у світі, найдоступніша для людей, найдешевша, зважаючи на обмежені ресурси сучасного українського суспільства, альтернатива офіційному судочинству, як процес досудового врегулювання спорів, що має багато переваг, на відміну від довготривалого судового розгляду.

За даними Міністерства юстиції України, починаючи з 2003 р. у судовій системі на експериментальних засадах активно впроваджується застосування медіаційних процедур. Значна роль у цьому процесі належить Регіональним групам медіації, діяльність яких спрямована, насамперед, на популяризацію медіації, впровадження програм примирення та діалогу. Відсутність державних інституцій, нормативного забезпечення, інформаційної підтримки та чіткого механізму реалізації $\epsilon$ свідченням того, що на цьому етапі медіація в Україні функціонує переважно на громадських засадах.

За відсутності спеціального закону певні можливості для впровадження медіації в юридичну практику та практику надання правничої допомоги в Україні надає галузеве законодавство. Так, ч. 6 ст. 16 Закону України «Про соціальні послуги» медіація визнається базовою соціальною послугою, а ч. 2 ст. 7 Закону України «Про безоплатну правову допомогу» закріплюється, що безоплатна первинна правова допомога включає такий вид правової послуги, як надання допомоги в забезпеченні доступу особи до медіації [12; 7].

У серпні 2019 р. Україна підписала в Сінгапурі Конвенцію ООН щодо медіації, яка спрямована на те, аби в майбутньому транскордонні комерційні спори частіше вирішували за допомогою посе- 
редництва (медіації) та шляхом укладання мирових угод [17]. Підписання Сінгапурської Конвенції Україною підвищує авторитет та довіру до процесу медіації як альтернативного засобу врегулювання спорів та позитивно впливає на імідж країни на міжнародній арені, а також на розвиток міжнародної торгівлі та бізнесу в Україні.

Вищезазначене дає змогу узагальнити низку проблем на шляху інституціоналізації практики медіації в Україні. Серед найбільш актуальних проблем сучасні дослідники виділяють недосконалість нормативно-правової бази медіації в Україні, відсутність корпусу кваліфікованих медіаторів-практиків і низький рівень обізнаності населення щодо медіації та іï переваг. Впровадження медіації в Україні має регіональний характер, а отже, географія поширення виглядає фрагментарно. У частині регіонів склалася певна практика надання медіативної допомоги, реалізації освітніх програм у сфері медіації, а в інших регіонах вона тільки формується. Критерієм тут виступає рівень зацікавленості і активності професійних об'єднань.

Рекомендаційні акти Комітету Міністрів Ради Європи щодо медіації пропонують включити до кодексів професійної поведінки адвокатів обов'язок або рекомендацію щодо вжиття заходів із надання дотичної інформації та, де це можливо, запропонувати сторонам вдатись до медіації, в тому числі між потерпілим і правопорушником, та подання клопотання стосовно передачі справи на медіацію до відповідно уповноваженого органу. Адвокатським колегіям і правничим об'єднанням рекомендується мати списки тих, хто надає послуги медіації, і поширювати їх серед адвокатів. Ю. Рємєскова вважає, що в Україні медіація маєвизнаватися як особливий вид адвокатської діяльності, що має знайти своє закріплення і на рівні чинного законодавства про адвокатуру та адвокатську діяльність. У наданні правової допомоги учасникам кримінального провадження в процесі проведення медіації значні можливості і перспективи $\epsilon$ саме в адвокатів-медіаторів, які $\epsilon$ потенційним джерелом скеровування правопорушників для участі у програмах відновного правосуддя. Вони мають відігравати важливу роль у роз'ясненні сторонам користі від участі в процедурах відновного правосуддя i, таким чином, забезпечувати реалізацію їхнього права на примирення у випадках, встановлених законом [14, с. 91]. Під час здійснення медіативної діяльності адвокат не $\epsilon$ ані особою, уповноваженою вирішити спір (конфлікт), ані представником або консультантом лише однієї зі сторін спору. Медіатор зобов'язаний медіювати спір, дотримуючись принципу нейтральності і без упереджень стосовно сторін та предмета спору.

Адвокат, якому відомі і зрозумілі процедура медіації, іï принципи, правила і відмінності від інших способів вирішення спорів, може відігравати позитивну і конструктивну роль як учасник окремої справи, стимулюючи просування справи, відслідковуючи змістовну частину процесу, допомагаючи гнучкості сторін, так і як провідник медіації.

Найчастіше адвокати залучаються до проведення медіації в цивільному процесі, в комерційних конфліктах, розділі майна у сімейних конфліктах. Адвокати мають поважати принцип самовизначення сторін, який дозволяє сторонам приймати рішення, що не завжди ґрунтується на правовій позиції, але відображає інтереси сторін і задовольняє обидві сторони.

Інтерес адвокатів до медіації зумовлений пошуком нових сфер діяльності та потребою у підвищенні кваліфікації. Л. Романадзе підкреслює, що в Україні дедалі більше адвокатів «пірнають» у тему медіації та намагаються 3'ясувати їі ефективність для своїх клієнтів. Авторка вважає, що медіація відкриває нові можливості для адвокатів в їхній професійній діяльності: по-перше, оволодіння навичками медіатора підвищує рівень професійної майстерності адвоката; по-друге, медіація відкриває новий напрям у професійній діяльності адвоката - супровід клієнта у процедурі медіації; по-третє, адвокат сам може виконувати функцію медіатора, що прямо передбачено ч. 2 ст. 21 Правил адвокатської етики. У цьому випадку, окрім правил адвокатської етики, дії адвоката мають відповідати міжнародно визнаним етичним засадам медіації [15].

Отже, за сучасних умов медіація - це вид альтернативного врегулювання спорів, метод їх вирішення із залученням посередника (медіатора), який допомагає сторонам конфлікту налагодити процес комунікації і проаналізувати конфліктну ситуацію так, щоб вони самостійно змогли вибрати той варіант рішення, який би задовольняв інтереси і потреби усіх учасників конфлікту. На відміну від формального судового процесу, під час медіації сторони доходять згоди самостійно медіатор не приймає рішення за них. Медіація як один з альтернативних способів регулювання правових конфліктів є важливим інструментом удосконалення правової культури суспільства. Це складний процес, проте завдяки йому професійно 
підготовлений фахівець - медіатор - може знайти вигідне рішення для обох сторін. ІЇ̈ розвиток може здійснюватися лише в умовах добровільної згоди і усвідомлення громадянами раціонального участі медіатора, який зацікавлений у вирішенні конфліктних ситуацій, досягнення єдиного рішення на основі взаємної згоди сторін спору, який не допускає будь-якого фізичного впливу або маніпуляції. Будь-який механізм інформування сторін спору має спиратися на розвинену систему медіації та медіаторів, що вимагає визнання державою та її підтримки такого методу вирішення спорів.

Ефективним механізмом впровадження інституту медіації в Україні має, насамперед, стати законодавче визначення принципів здійснення медіації, закріплення чіткого порядку проведення процесу медіації, визначення прав, обов'язків і відповідальності медіатора, передбачення вимог до договору медіації та його виконання, а також спеціальних положень щодо медіації різних конфліктів: цивільних, сімейних, трудових, господарських, конфліктів, пов'язаних із захистом прав споживачів, медіації в кримінальних провадженнях та справах щодо адміністративних правопорушень.

Крім того, інститут медіації, який отримує нині дедалі більше визнання громадянського суспільства, може використовуватися, на наш погляд, не тільки як самостійна процедура для ефективного вирішення конфлікту, а й як цілеспрямована соціальна програма формування цільового ціннісного простору для відродження i формування соціально значущих орієнтирів суспільства.

Висновки. Можна констатувати, що, не маючи законодавчого підґрунтя, медіація в Україні все ж таки стає соціальним інститутом, який формується через об'єктивну потребу в допоміжній для правосуддя системі, яка дасть змогу розвантажити судову систему, забезпечити іï ефективне функціонування, вирішувати наявні спори у швидкий, помірно витратний, конфіденційний та ефективний спосіб. На наш погляд, законодавче регулювання процедури медіації розширить альтернативні способи вирішення спорів, дасть змогу сторонам врегулювати спір у позасудовому порядку, що сприятиме вдосконаленню в Україні механізмів захисту прав людини і громадянина. Важливим $\epsilon$ те, що, на відміну від судової процедури вирішення спору, в якій завжди $\epsilon$ сторона, яку не влаштовує рішення суду, в процедурі медіації сторони самостійно приймають рішення, яке задовольняє сторони спору.

Зазначимо, що запровадження інституту медіації в України як форми захисту прав громадян створює умови для пошуку неординарних, життєздатних, стійких рішень. За сучасних умов механізм впровадження інституту медіації набирає позитивних обертів. Науковці, судді, адвокати, представники громадянського суспільства одностайні в тому, що медіація $\epsilon$ ефективною альтернативою судовим спорам. Розвиток процедури досудового розгляду в Україні стає дедалі більш популярним та сприятиме якнайшвидшому становленню громадянського суспільства, в межах якого громадяни дійсно зможуть регулювати конфлікти без участі і контролю з боку держави. Крім того, медіацію варто розглядати як форму філософії діалогу, яка може бути застосована не тільки як спосіб вирішення конфлікту, але і як форма продуктивного спілкування в процесі активного користування техніками, якими має володіти медіатор.

\section{Література}

1. Гірник А.М. Основи конфліктології. Київ : Вид. дім «Києво-Могилянська академія», 2010. 222 с.

2. Денисова Р.О. Інститут медіації в Україні (національно-історичний аспект). Теорія і практика правознавства. 2018. Вип. 1 (13). С. 1-9.

3. Европейский кодекс поведения для медиатоpов. URL: https://mediation-eurasia.pro/wp-content/ uploads/2018/04/evropejskij-kodeks-povedenija-dljamediatorov.pdf

4. Кодекс етики медіатора Національної асоціації медіаторів України. URL: http://namu.com.ua/ ua/info/mediators/ethical-code/

5. Крестовська Н., Романдзе Л., Барабаш Т. Медіація в Україні: нюанси законодавчого врегулювання. Юридичний вісний України: все про закони - в одній газеті. 2017. № 9. С. 13. URL: http:// mediation.ua/wp-content/uploads / 2017/03/ stattyaMediatsiya-v-Ukrayini-nyuansi-zakonodavchogovregulyuvannya.pdf.

6. Мазаракі Н. Медіація в Україні: проблеми теорії та практики. Зовнішня торгівля: економіка, фінанси, право. 2016. № 1. С. 92-100.

7. Про безоплатну правову допомогу : Закон України. № 3460-VI від 04.11.2018 р. URL: https:// zakon.rada.gov.ua/laws/show/3460-17

8. Про діяльність в сфері медіації : проєкт Закону України № 10425 від 05.07.2019 p. URL: https://w1.c1. rada.gov.ua/pls/zweb2/webproc4_1?pf3511=66139

9. Про медіацію : проєкт Закону України № 3504 від 19.05.2020 p. URL: http://w1.c1.rada.gov.ua/pls/ zweb2/webproc4_1?pf3511=68877

10. Про медіацію : проєкт Закону України № 3665 від 17.12.2015 р. URL: http://w1.c1.rada.gov.ua/pls/ zweb2/webproc4_1?pf3511=57463 
11. Про прийняття за основу проєкту Закону України про медіацію : Постанова Верховної Ради України. від 15.07.2020 р. URL: https://zakon.rada.gov.ua/ laws/show/796-20\#Text

12. Про соціальні послуги : Закон України № 2671VIII від 17.01.2019 р. (введення в дію 01.01.2020). URL: https://zakon.rada.gov.ua/laws/show/2671-19

13. Про Стратегію реформування судоустрою, судочинства та суміжних правових інститутів на 2015-2020 роки : Указ Президента України 20 травня 2015 року № 276/2015. URL: https: / /zakon2.rada.gov. ua/laws/show/276/2015

14. Рємєскова Ю.О. Медіація як особливий вид адвокатської діяльності в Україні. Актуальні проблеми судового права : мат. міжнар. наук.-прак. конф. / НЮУ ім. Яр. Мудрого. Харків, 2015. С. 88-91. URL: http://dspace.nlu.edu.ua/ bitstream/123456789/10720/1/Remeskova_88-91.pdf

15. Романадзе Л.Д. Медіація в професійній діяльності адвоката. URL: http://dspace.onua.edu.ua/ bitstream/handle/11300/10983/Romanadze\%20L\%20D. pdf?sequence $=1$ \&isAllowed $=y$
16. Ясиновський І.Г. Проблеми впровадження та проведення медіації в Україні. Актуальні проблеми політики. 2015. Вип. 55. С. 260-267.

17. Sussman E. (2018) The Singapore Convention. Promoting the Enforcement and Recognition of International Mediated Settlement Agreements. ICC Dispute. URL: https://sussmanadr.com/wp-content/ uploads / 2018/12/ICC-Singapore-ConventionSussman-10-2018-2.pdf

Матвєєва Л. Г., доктор юридичних наук, доцент, завідувач кафедри теорії та філософії права Одеського державного університету внутрішніх справ

https://orcid.org/0000-0002-8402-5584

Балтаджи П. М., кандидат юридичних наук, доцент, професор кафедри державно-правових дисциплін Одеського державного університету внутрішніх справ 